\title{
Clinical Characteristics of Patients with Fibromyalgia
}

\author{
Mustafa Guler, M.D., Mehmet Kirnap, M.D., Gurcan Uremke, PT \\ Trabzon, Turkey
}

DOI: http://dx.doi.org/10.5915/23-2-15074

\begin{abstract}
Fibromyalgia fibrositis is a common noninflammatory, painful muskuloskeletal disorder. It is commonly seen between the ages of 40 and 60 and has a 5:1 female to male ratio. Essential symptoms of fibrositis are disturbed sleep, morning stiffness, and local tender points. Subjective swelling, paresthesia, and numbness sometimes may be seen. Multiple host and environmental factors seem to contribute to the onset and course of fibromyalgia. Modest improvement follows treatment by antidepressive agents, by physical measures and by reduction in stress.

In this study, 60 patients with fibromyalgia were investigated and the clinical characteristics were delineated and compared with other studies. We found that mean age (37.4 years) was lower and the common sites were neck, low back, and shoulder. Stress, fatigue, and climate were the usual associated factors.
\end{abstract}

Key words: Fibromyalgia, clinical features, musculoskeletal system

Fibromyalgia is a common noninflammatory, painful musculoskeletal disorder. This syndrome has been called by many names including neurasthenia and rheumatism. Many clinical and etiologic associations have been described. ${ }^{1-13}$ We have evaluated patients with this syndrome seen at the Black Sea Technical University and present the findings in this paper.

Fibrositis is a syndrome of the musculoskeletal system which is usually seen in clinical practice. Although the term most used is fibrositis, other terms such as rheumatism, muscle rheumatism, neurasthenia, or neurosis have been used for

From the Department of Physical Medicine and Rehabilitation, and Psychiatry

Black Sea Technical University

Reprint requests: Mustafa Guler, M.D. Department of Physical Therapy and Rehabilitation KUT Tip Fakultesia, Farabi Hstanesia FTR Anabilim Dali, Trabzon, Turkey fibrositis. The most typical symptoms of the disease are pain which arises by pressure in neck, shoulder, back, low back, and gluteal regions..$^{1-3}$ In this disease, which is usually seen in women between the ages of $40-60$, complaints such as pain, stiffness, emotional upsets, and fatigue increase with cold and immobilization. ${ }^{4,5}$ By contrast, complaints decrease with heat, massage, exercise, and rest. Clinically, this disease may be primary or secondary. In secondary fibrositis, the main pathology usually underlines another disease. But in primary fibrositis, pathology is in muscle and other symptoms are seen after the primary muscle pathology. Fattening and some degenerative variations in muscle fibers, cell infiltration, and proliferation in connective tissue are seen in muscle biopsies which are taken from painful and tender regions. ${ }^{10,12}$ The blood and urine analyses of patients with fibrositis are usually within normal limits. The most common factors associated with the disease are emotional upsets, postural disturbances, stress, trauma, and climate. For diagnosis, the presence of local tender points and chronic fatigue are usually helpful. For therapy, good doctor/patient 
Table 1. Other clinical findings associated with fibrositis

\begin{tabular}{lcc}
\hline Findings & Number & Percentage(\%) \\
\hline Morning Pain & 36 & 60 \\
Morning Stiffness & 42 & 70 \\
Chronic Fatigue & 40 & 66.7 \\
Sleeping disturbances & 52 & 86.7 \\
Gastrointestinal & & \\
$\quad$ disturbances & 30 & 50 \\
Headache & 28 & 46.7 \\
Menstrual Changes & 9 & 15 \\
Paresthesia & 16 & 26.7 \\
$\begin{array}{l}\text { Depressive complaints } \\
\text { Subjective soft tissue }\end{array}$ & 22 & 36.7 \\
$\quad$ swelling & 12 & 20 \\
Cardiovascular problems & & \\
$\quad$ (Dizziness, palpitation) & 18 & 30 \\
\hline
\end{tabular}

relation is necessary. Breaking the pain-spasm-pain vicious cycle is the main goal of therapy. With the use of antirheumatic drugs, sedatives, vitamins, physical therapy modalities, massage and psychotherapy, some degree of recovery can be obtained. ${ }^{3-5}$

\section{Materials and methods}

In this study 60 patients were investigated in the Physical Medicine and Rehabilitation, Psychiatry, Orthopaedia and Traumatology departments at the Black Sea Technical University medical faculty. They were evaluated as to sex, age, disease localization, and socioeconomic characteristics. The diagnostic criteria included generalized musculoskeletal ache or pain lasting three or more months, painful tender points in painful regions, symptomatic complaints which increase with anxiety, cold weather, stress, and insomnia. Headache, gastrointestinal symptoms, chronic fatigue and paresthesia also had to be present in patients. Patients were evaulated in respect to their clinical and laboratory findings.

\section{Results}

In our study, $78 \%$ of patients were female and the mean age was 37.4 years with range between 19 to 55 years. The disease duration ranged from three months to ten years with a mean duration of 2.8 years. Forty percent of patients had primary school education, $33 \%$ had high school, $17 \%$ had university education, and $10 \%$ had no education. Seventy-three percent of fibrositic patients were married, $20 \%$ were single $7 \%$ were widowed. Pain sensation was rated as follows: 0 = no pain, $1=$ mild, $2=$ moderate, $\mathbf{3}=$ severe. The mean pain sensation score was calculated as 2.2. Fifty-three percent of our patients were housewives, $18 \%$ office workers, $15 \%$ workmen, $5 \%$ students, and $9 \%$ were in other professions. Our pa-
Table 2. Etiological factors for fibrositis

\begin{tabular}{lrrrcc}
\hline $\begin{array}{l}\text { Etiological } \\
\text { causes }\end{array}$ & \multicolumn{2}{c}{ To be cause } & & \multicolumn{2}{c}{ To be associated with } \\
\cline { 2 - 3 } \cline { 5 - 6 } & Number & $\%$ & & Number & $\%$ \\
\hline Climate & 3 & 5 & & 20 & 33.3 \\
Stress & 32 & 53.3 & & 35 & 58.3 \\
Fatigue & 4 & 6.7 & & 42 & 70 \\
Trauma & 9 & 15 & & 16 & 26.6 \\
Operation & 3 & 5 & & 3 & 5 \\
Death in & & & & \\
$\quad$ family & 4 & 6.7 & 2 & 3.3 \\
Idiopathic & 5 & 8.3 & 6 & 10 \\
\hline
\end{tabular}

tients had used a number of therapy modalities and they had been relieved in different ratios. Ninety percent of fibrositic patients had used medications. These medications included, NSAIDS $(45 \%)$, steroids $(20 \%)$, sedatives $(40 \%)$, antidepressives $(17 \%)$, and analgesic medications $(62 \%)$. On the other hand, $13.3 \%$ of patients were relieved by exercise, $23 \%$ by rest, $35 \%$ by sleeping, $28 \%$ by physical therapy modalities, and $22 \%$ by other therapy forms. In our study, many of our patients complained of other secondary clinical findings which are not unusual of fibrositis (Table 1).

In our cases, stress was an important etiological factor for disease and some other factors could have played an important role for the beginning precipitation of disease (Table 2).

Fibrositis was usually located in low back, cervical, gluteal, knee, and elbow regions (Table 3).

\section{Discussion}

Musculoskeletal system disorders are the second most common group of diseases which cause loss of work and are secondarily important in the chronic disease group. ${ }^{1,4}$ Although there are many investigations about rheumatoid arthritis, osteoarthritis, and other rheumatic diseases, fibrositis is a subject which has been neglected. Recent studies have shown that fibromyalgia is a rheumatic disease which is usually seen in clinical practice. ${ }^{2}$ But the socioeconomic aspects of this disease are different. Investigations have suggested that although fibromyalgia is a disease which causes severe pain and discomfort, it doesn't usually lead to severe functional loss.'s

Fibromyalgia is usually seen between the ages of 40-60. In his study, Wolfe observed the mean age as 52.9 and beginning age of disease as $34 .{ }^{4,8}$ Yunus et $\mathrm{al}^{12}$ described the incidence of the disease between the ages of $9-15$ as $28 \%$. In our study, we found the beginning age was 24.2 and mean age was 37.4 years. A group of investigators reported that the female/male ratio is $6: 1 .^{4}$ In our study, $78 \%$ of the fibrositic patients were female and $22 \%$ of the patients were male. Fibromyalgia is usually seen in two different forms. In our study, chronic type disease 
Table 3. Localization of the tender region

\begin{tabular}{lcccccccc}
\hline Region & Cervical & Trapezius & $\begin{array}{c}\text { Costo- } \\
\text { chondral }\end{array}$ & Elbow & Lowback & $\begin{array}{c}\text { Gluteus } \\
\text { medius }\end{array}$ & Knee & $\begin{array}{c}\text { Supra- } \\
\text { spinatus }\end{array}$ \\
\hline Right & - & 25 & 26 & 9 & - & 15 & 13 & 20 \\
Left & - & 16 & 4 & 6 & - & 13 & 8 & 8 \\
Bilateral & 44 & 9 & 2 & 3 & 41 & 5 & 3 & 6 \\
Female & 34 & 24 & 6 & 10 & 30 & 18 & 15 & 13 \\
Male & 10 & 8 & 2 & 2 & 11 & 5 & 3 & 8 \\
Total & 44 & 32 & 8 & 12 & 41 & 23 & 18 & 21 \\
\% & 73.3 & 53.3 & 13.3 & 20 & 68.3 & 38.3 & 30 & 35 \\
\hline
\end{tabular}

was present in $65 \%$, and the intermittent type was seen in $35 \%$ of the patients.

The prevalence of the disease in the population is not well established. Masi concluded the prevalence of fibromyalgia as 2 in 100,000 people. ${ }^{4}$ The prevalence of the disease in rheumatology clinics is between 14-20.4 The prevalence of fibromyalgia in among other disease is 5 to $7 \% .^{3}$ A number of patients had secondary fibromyalgia in our study. Investigators reported that the ratio of secondary to primary is $3: 1 .^{3,4}$

In our cases, there were many different etiological factors. Yunus et al and Wolfe reported the association of the following with fibrositis: trauma $24 \%$, stress $14 \%$, idiopathic causes $5 \% .^{12,5}$ Associated with these etiological factors there are some other aggravating factors. Some etiological factors such as climate, stress, fatigue, trauma, surgical intervention, death in the family, and change in the family have been suggested as a cause for the beginning and the recurrence, in percentages of 15-17, 35-45, 22-39, $24,13,25$, respectively. ${ }^{7,5,11,12}$ In contrast, in our study we observed that cold weather $(20 \%)$, stress $(58 \%)$, fatigue $(70 \%)$, trauma $(26 \%)$, surgical intervention $(5 \%)$, death in the family $(7 \%)$, and idiopathic factors $(18 \%)$ could be the cause for the beginning and recurrence of fibromyalgia.

Cathey et al reported $89 \%$ of their patients were graduates from high school and $84 \%$ were married, $4 \%$ single, and $4 \%$ widowed. ${ }^{13}$ In our patients, $73 \%$ were married, $20 \%$ single, and $7 \%$ widowed and most of our patients were not well educated. Forty percent had primary school, $33.3 \%$ high school, $6.7 \%$ university education.

In respect to the localization of the disease, in our study the disease locations included neck $(73.3 \%)$, lowback $(68.3 \%)$, trapezius $(53.3 \%)$, and costochondral region $(13.3 \%)$. Some researchers reported that the fibromyalgia is seen $55-60 \%$ at lowback, neck and shoulder region, $35-40 \%$ at the chest region, and $15-20 \%$ at other regions such as knee, elbow and gluteal region. ${ }^{1,4,14}$

There are many clinical findings which could be associated with fibromyalgia. According to Campbell insomnia was seen $100 \%$ and chronic fatigue $70-100 \%$ in the patients with fibromyalgia. ${ }^{1}$ In some investigations, headache was seen in $45 \%$, half of whom were suffering from migraine. ${ }^{8}$

In patients with fibrositis, other systemic complaints can be found such as gastrointestinal symptoms (constipation and diarrhea), Raynaud's phenomenia and paresthesia, $35-50 \%, 9 \%$, and $32 \%$, respectively. ${ }^{1,8,9}$ Morning stiffness is usually seen in fibromyalgia and usually with long duration. Sixty percent of our patients suffered from morning pain; morning stiffness $70 \%$, chronic fatigue $66.7 \%$, menstruation distrubances $15 \%$, paresthesia $26.7 \%$, headache $46.7 \%$, depressive complaints $36.7 \%$, other subjective complaints $27 \%$, and cardiovascular complaints $30 \%$.

Classically, the risk of involvement on the right side appears higher than on the left side.' The results of our investigation also showed that the right side involvement was higher than the left side.

Fibromyalgia has been treated with a number of therapeutic modalities with variable degrees of recovery. Cathey et al concluded $91 \%$ NSAIDs, $32 \%$ antidepressive drugs, $18 \%$ anxiolytic drugs, $4 \%$ steroids, $33 \%$ hormones, $22 \%$ vitamins, and $1 \%$ other myorelaxant medications have been used for the therapy of fibromyalgia..$^{8-13}$ Wolfe reported fibromyalgia can be treated in $25 \%$ of the patients with activity, $32 \%$ with excercise, $47 \%$ with relaxation technique, $30.5 \%$ with weight loss, $65.7 \%$ with rest, $35 \%$ with steroids, $36 \%$ with antidepressive medications. The total recovery rate was $34.5 \%$ in patients who used medications and $38.7 \%$ who used other therapeutic modalities. ${ }^{4,8}$ In our study, we found that $13 \%$ of the patients were relieved by exercise, $23 \%$ by rest, $35 \%$ by sleep, $90 \%$ by medication, $40 \%$ with the use of sedatives, $16.6 \%$ with antidepressive agents, $28.3 \%$ with physical therapy, and $22 \%$ with the use of other therapeutic modalities.

In summary, we found that the mean age of our patients was lower than it has been previously reported. The prevalence of the disease was higher in females than males. Our patients were usually using antirheumatic drugs for therapy. Stress, fatigue and climate were the most important etiologic factors. Neck, lowback, and shoulder were the usual sites. 


\section{References}

1. Campbell SM: Clinical characteristics of fibrositis. I.A. "blinded" controlled study of symptoms and tender points. Arth Rheurn $1983 ; 26: 817$.

2. Masi AT, Yunus MB: Concepts of illness in populations as applied to fibromyalgia syndrome. Am J Med 1986;81:19-25.

3. Hadler NM. A critical reappraisal of the fibrositis concept Am J Med 1986;81:26-30.

4. Wolfe E: The clinical syndrome of fibrositis. Am J Med 1986;81:7.

5. Symthe HA: Fibrositis and other diffuse musculoskeletal syndrome. In: Textbook of Rheumatology, first ed., Kelley WN et al, eds, Philadelphia: WB Saunders Co, 1981;481.

6. Gatter RA: Pharmacotherapeutics in fibrositis. Am J Med 1986;81:63-6.

7. Goldenberg DL: Psychologic studies in fibrositis. Am J Med 1986;81:67-70.
8. Wolfe E. Development of criteria for diagnosis of fibrositis. Am J Med 1986;81-99.

9. Turek SL. Fibrositis. In: Orthopaedics and Principles and Their Application, third ed, Philadelphia: JB Lippincott Co, 1977;1409.

10. Symthe HA: Non-articular rheumatism and psychogenic musculoskeletal syndromes, arthritis and all condition. McCarty, DJ, ed, ninth edition. Philadelphia: Lea Febiger, 1979;881.

11. Tuna N: Fibrositis Syndrome. Textbook of Rheumatic Disease. Hacettepe Tas Co. Ankara, $1982 ; 605 S$.

12. Yunus M, Masi AT, Calabro JJ, Shah IK : Primary fibromyalgia syndrome. Sem Arthrifis Rheum 1981;11:151.

13. Cathey MA, Wolfe F, Kleinheksel SM, Howley DJ: Socioeconomic impact of fibrositis. A study of 81 patients with primary fibrositis. Am J Med 1986;81:78-84. 